\title{
ヒト血中リポタンパクサブフラクションのコレステロール 分布測定用バイオリアクターシステム
}

(1.986 年 8 月 13 日受理)

\author{
牧野圭 祐*・佐々木一郎・上西 徹 \\ 武内民男・原一郎**・海野益 郎**
}

本研究は心筫梗塞に密接に関連する血中リポタンパクサブフラクション中のコレステロールエステル 含有量を測定するための自動臨床分析法の開発に関するすのである。具体的には，リポタンパク中の コレステロールエステルに反応し，最終的に過酸化水素を生じるコレステロールエステルヒドラーゼ (CEH) およびコレステロールオキシダーゼ (COD) を, リポタンパクと相互作用のない排除クロマ トグラフィー用ゲルに固定化し，これをバイオリアクター型検出器として, リポタンパク分離用の排 除クロマトグラフィー用カラム後方に接続した。 $\mathrm{CEH}$ 抌よび COD はグルタルアルデヒドをスペーサ 一として用いることで固定化できた。このシステムで生成した過酸化水素をオンラインで発色すること で， $550 \mathrm{~nm}$ に吸收極大をすつキノンジイミン色素を生成し，これをモニターしたところ，低密度执よ び高密度リポタンパクに由来するピークを得た。この溶出挙動は, 過去に報告された CEH 拈よび COD を水溶液発色剤として消費する方法によって得られた結果とよい相関をみた。またピークの溶出容量, 理論段相当高, 面積を詳細に検討したところ, これらが本研究の目的である高脂血症の型の認識を可 能にすることを見いだした。以上のように本研究は，今日の最大死因の一つである心筋梗塞を予知し， また治療経過をもニターするのに大きな可能性をるつ方法を提供するものである。さらに本研究で得た ハイホリリアクター型検出器は血中リポタンパクを選択的に(特異的に) 検出するものであり，「分子認識 とその応用」という今回の課題に適合するすのであると考兄る。

\section{1 緒 言}

醉素は，生体成分の一つを巧妙に認識し，これと特異的に反応 する。よって, 複傕な混合物中の特定の微量成分の検出に優れ る。このような理由から、䤃素は臨床化学分析では微量分析試䍒

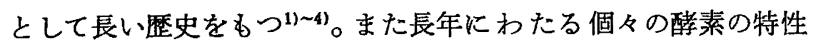
飞関する研究の結果, 詳細な取りあつかい方法が明らかとされて おり，このため今日，酔素は臨床化学分析で広範に使用される。 臨床化学分析においては, 連続して供給される試料に対応するた め多量の酵素が必要とされるが，今日これは微生物発醇により十 分に供給される。しかしながら，䣼素の価格は依然として高く，

京都工芸織維大学緎維学部高分子学科, 606 京都市左京 区松ヶ崎

** 東洋曹達工業株式会社科学計测事業部, 252 綾瀬市早川

1) E. K. Jr. Marshall, J. Biol. Chem., 15, 487(1913).

2) E. Praetorius, H. Poulsen, Scand. J. Clin. Lab. Invest., 5, 273(1953).

3) W. Richmond, Clin. Chem., 19, 1350(1973).

4) C. C. Allain, L.S. Poon, C. S. G. Chan, W. Richmond, C. $\mathrm{Fu}$, ibid., 20, 470(1974).
現代医学を支える臨床化学分析に関するコストの引き下げは，い まな扰重要な研究課題である。以上の問題解決のため, 固定化醉 素法の臨休化学分析への導入が行なかれだ。この方法のるっと も有利な点は，酵素を水溶解しない支持体に固定することで， その再利用が可能になることである。さらには，固定化すること により酵素本来の至適温度あるいは至適 $\mathrm{pH}$ を変化させること ができたり，使用時の安定性が增すなぞ、醅素活性を利用するた めに有利な条件が発現することがある。また，䤃素を固定化して 用いる場合，カラムに充填するなどの操作む可能であり，これを 流路系に組み込むことができる。

固定化醭素を自動臨床化学分析に応用したシステムは, 二つの タイプに分類できる。一つは，血中グルコースなどの測定到に代 表されるように，目的成分の総量を求める場合であり，この上う な場合に固定化酵素はオートアナライザーやフローインジェクシ

5) N. Grubhofer, L. Schleith, Naturwissenschaften, 40 , 508(1953).

6) T. Murachi, Y. Sakaguchi, M. Tabata, M. Sugahara, J. Endo, Biochimie, 62, 581(1980). 
ョンの流路系に組み込まれる778)。ほかは，胆汁酸などのアイソザ イムの相対量を求める場合であり，同様に固定化酵素は流路系に 組及込まれるが，この場合，定量前に目的成分を分離する操作が 必要である ${ }^{9)}$ 。のよ5な测定は，前者にくらべ，個々の成分の 正確な量が決定できることおよびそのパターン分析が可能といら 点で優れている。

本研究に招いては，上に述べた第二の方法の応用として，心管 梗塞などの動脈硬化性疾患と関係の深い高脂血症を検出すること を目的として，ヒト血中リポタンパクの高速液体クロマトグラフ 1ー（HPLC）による分離と，固定化酵素カラムを具備したバイ オリアクター型検出システムを組み合わせた自動分析システムの 開発を行なった。とくに，すでに報告されたように年，上記の疾 患はリポタンパクサブフラクションの代謝異常による高コレステ ロール含有リポタンパクサブフラクションの蓄積に起因するの で, 本研究では, いての検討を行なった。また得られた結果は，過去に報告された

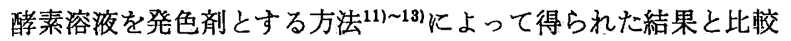
した。

\section{2 実 験}

試料として用いた七ト血清は，12〜16 時間の fasting 後の健常 人あるいは高脂血症患者から得た。コレステロールェステルヒド ラーゼ (EC 3.1.1.13 Pseudomonas fluorescence 由来) (以下 $\mathrm{CEH}$ と略記する) 拉よびュレステロールオキシダーゼ (EC 1.1. 3. 6 Brevibacterium sterolium 由来) (以下 COD と略記する) は 協和メデックスから供給された。酉洋ワサビ由来のペルオキシダ 一ゼ (EC 1.11.1.7)（以下 POD と略記する）はベーリンガーマ ンハイム山之内から睛入したものを用いた。CEH および COD の固定化支持体として用いた排除クロ、トグラフィー用ゲル G $6000 \mathrm{PW}$ は東洋曹達工業から得た。G $6000 \mathrm{PW}$ はトシル化を行 なったのら，プロピレンジアミンと反応させアミノ化して用い た。発色反応に用いる 4-アミノアンチピリン（以下 4-AA と略 記する)， $N$-エチルーN-(2-ヒドロキシー3-スルホプロピル)-m-ト ルイジン（以下 TOOS と略記する）は同仁化学研究所から購入 し、ポリオキシェチレンー(10)ーオクチルフェニルエーテル（商品 名 Triton X-100) は和光純薬工業から購入した。なお，Triton X-100 は，購入した中に，POD，4-AA，TOOS 存在下で発色す るものがあり $(550 \mathrm{~nm})$ ，あらかじめ発色反応を行なわない Triton X-100を用いた場合る水中に添加したのち，室温で放置する らちに発色を行ならすのがあったため, 冷所保存して用いた。こ こで, Triton X-100 は，水溶液とリポタンパクとの親和性を增

7) J. Endo, M. Tabata, T. Murachi, Clin. Chim. Acta, 95, 411(1979).

8）田畑勝好，福永千桂子，末戸隆宏，村地 孝，日本臨床检 査自動化学会誌, 8, 801(1983).

9) S. Okuyama, N. Kokubun, S. Higashidate, D. Uemura, Y. Hirata, Chem. Lett., 1979, 1443.

10) M. S. Brown, P. T. Kovanen, J. L. Goldstein, Science, 212, 628(1981).

11) I. Hara, M. Okazaki, Y.Ohno, J. Biochem., 87, 1863 (1980).

12) M. Okazaki, Y.Ohno, I. Hara, ibid., 89, 879(1981).

13) M.Okazaki, K.Shiraishi, Y.Ohno, I. Hara, J. Chromatogr., 223, 285(1981).

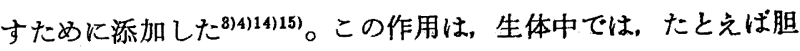
汁酸が行なっている。ほかの試薬は半井化学から購入したものを 用いた。使用した水は Milli R/Q 純水装瞋 (Millipore, Bedford, MA., USA) で精製した。

CEH および COD の $\mathrm{G} 6000 \mathrm{PW}$ への固定化は以下の方法で行 なった。アミノ化した G $6000 \mathrm{PW}\left(0.5 \mathrm{~cm}^{3}\right.$ ，湿潤状態）を $2.5 \%$ グルタルアルデヒド水溶液 $\left(10 \mathrm{~cm}^{3}\right)$ 中で活性化した ${ }^{16)} 211$ 。反応 は, ゲル中の気泡を除去するため, 最初の 30 分間は室温減圧下 で行ない，その後 1.5 時間室温大気圧下で放置して行なった。活 性化したゲルをデカンテーションで水洗したのち,これに 2 $\mathrm{mmol} \cdot \mathrm{dm}^{-3}$ エチンンジアミン四酢酸 (以下 EDTA と略記する) を含む $150 \mathrm{mmol} \cdot \mathrm{dm}^{-8}$ リン酸塩緩衝液 $\left(3 \mathrm{~cm}^{8}\right)$ に溶解したCEH (0.6 mg, 62 unit) と COD (9.4 mg, 119 unit) を加えて, 室温 減圧下で 30 分間気泡を除去しながら反応を行ない,この後 $5^{\circ} \mathrm{C}$ で 1.5 時間反応を継続した。この後末反応の両酵素を水でデカン テーションして除去した。得られた固定化酵素は湿㵎状態で $5^{\circ} \mathrm{C}$ で保存した。ウシ血清アルプミンを検量線作成の標準物質として 用い， $280 \mathrm{~nm}$ の吸収から計算した固定化酵素のタンパク含有量 は湿潤ゲル $1 \mathrm{~cm}^{8}$ あたり $5.4 \mathrm{mg}$ であった。

得られた固定化酵素の活性測定は，一定量の固定化酵素 (10 $\mathrm{mg}$, 乾燥状態) $150 \mathrm{mmol} \cdot \mathrm{dm}^{-3}$ リン酸塩㗔衝液 $\left(2 \mathrm{~cm}^{3}\right)$ に加 えヒト血清 $\left(0.2 \mathrm{~cm}^{3}\right)$ を加えたのち， $40^{\circ} \mathrm{C}$ でかきまぜながら放 固し. 1 分後 $0.5 \mathrm{mmol} \cdot \mathrm{dm}^{-3} 4-\mathrm{AA}, 0.3 \mathrm{mmol} \cdot \mathrm{dm}^{-8}$ TOOS, 6.7 unit $/ \mathrm{mg}$ POD を加え着色量を $550 \mathrm{~nm}$ で測定することによ り行なった。

\section{3. 結 果と考察}

リポタンパクはタンパク，脂質，コレステロールエステルなど の複合体であり，カイロミクロン，超低密度りポタンパク (VLDL), 低密度りポタンパク (LDL), 高密度リポタンパク (HDL) などが存在する。すでに報告されているこれらの分離法

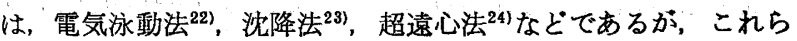
は自動分析法には適しない。また血清中での形状をたもちながら これらを分離する HPLC のモードはかぎられる。たとえば有機

14) Y. Uwajima, O. Terada, Agr. Biol. Chem., 40, 1957 (1976).

15) A. Noma, K. Nakayama, Clin. Chim. Acta, 73, 487 (1976).

16) M. Tabata, J. Endo, T. Murachi, J. Appl. Biochem., 3, 84(1981).

17) I. Sasaki, K. Makino, T. Takeuchi, H. Sasaki, J. Chromatogr., 332, 237(1985).

18) F. A. Quiocho, F. M. Richards, Proc. Nat. Acad. Sci., 52, 833(1964).

19), A.F. S. A. Habeeb, Arch. Bio. Biophys., 119, 264 (1967).

20) P. D. Weston, S. Avrameas, Biochem. Biophys. Res. Commun., 45, 1574(1971).

21) H. H. Weetall, L. S. Hersh, Biochim. Biophys. Acta, 185, 464(1969).

22) S. Raymond, J. L. Miles, J. C. J. Lee, Science, 151, 346(1966).

23) M. Burnstein, H. R. Scholnick, R. Morfin, J. Lipid Res., 11, 583(1970).

24）八杉忠男，佐々英一，木下 教，桑原慎次，最新医学; 27, 424(1972). 


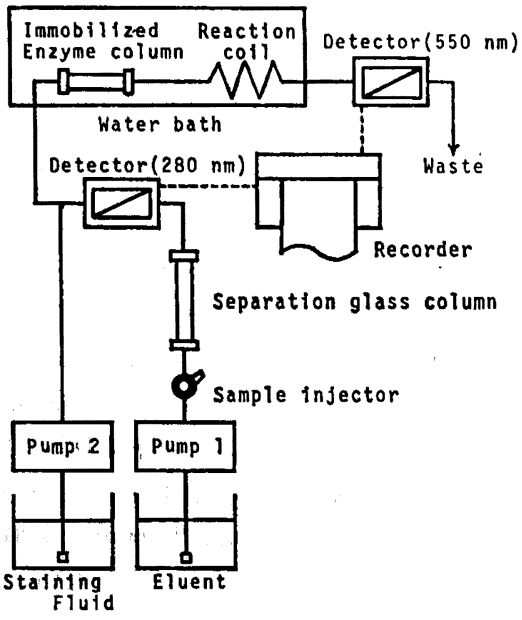

Fig. 1 Flow diagram of the cholesterol ester distribution determination system

溶媒を用いる逆相クロマトグラフィーでは形状の破損が生し，イ オン交換法ではリボタンパクサブフラクションの異なりを認識で きない。血中リボタンパクは，サブフラクションごとに粒子径が 異なるので, これを分離するには生体陚料との相互作用が小さく 分子贵の異なりによって分離を行なら排除クロマトグラフィーが 有効と考光られるが，過去に TSK-PW および SW シリーズのカ ラムを組み合わせて用いたとき，優れた結果が得られたと報告さ れている(1) 19)。よって今回の研究では, G $5000 \mathrm{PW}$ 単独あるいは G 5000 PW + G 3000 SW の組み合わせを用いた。因 1 にこのカラ ム列を組み込んた本研究で用いた装膡の概略を示す。困中示され たよ5に分離用カラムの出口には固定化醭菜カラムを接続し、こ の入口部には第二ポンブから送液される発色液を導き，分離され たりボタンバササブフラクションの固定化酵素上での反応で生成 する過酸化水案を発色肪と反応させた。これらの一速の反応をつ ぎに示す。

$$
\begin{aligned}
& \text { コレステロールエステル }+\mathrm{H}_{2} \mathrm{O} \text { ヨレステロールエステルヒドターゼ } \\
& \text { コレステロール十脂肪酸 }
\end{aligned}
$$

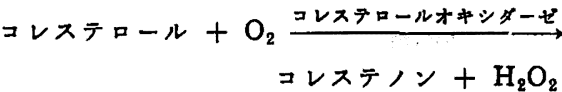

$$
\begin{aligned}
& 2 \mathrm{H}_{2} \mathrm{O}_{2}+4-\mathrm{AA}+\mathrm{TOOS} \stackrel{\text { ヘルルオキシダーゼ }}{\longrightarrow}
\end{aligned}
$$

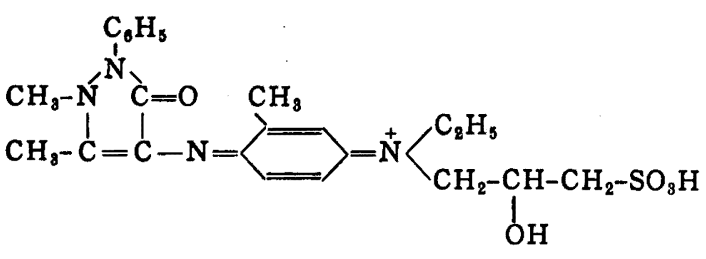

$$
\begin{aligned}
& +4 \mathrm{H}_{2} \mathrm{O}
\end{aligned}
$$

よって反応取終液 (溶離液) はリポタンパクサフフフラクション の分布およびそれらに含まれるコレステロール貫に比例した着色 を行なっており，この吸光度を测定することで本研究の目的は邀 成できる。すなわち，検出は着色反応生成物の最大吸収波艮であ り，ほかの血中タンパクの妨害を受けない550 nm で行なった。 つぎに，上記のシステムについての個々の部分の検討結果を示

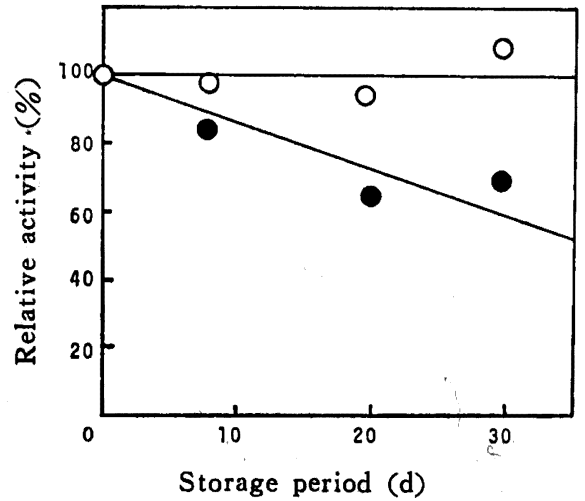

Fig. 2 Change in the activity of the immobilized enzyme during the storage

Storage conditions : wet (O), dry (O)

Temperature ; $5^{\circ} \mathrm{C}$, Sample ; Normal human serum

す。まず固定化酵素カラム調敒法について検討を行なった。実臥

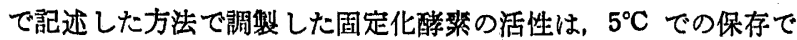
は, 1 か月以上変化しなかった。一方，倛燥状態で $5^{\circ} \mathrm{C}$ で保存し た埸合には 1 かで 40\% の活性低下がみられた（因 2)。湿潤状 態で安定であるという特徽は，固定化酵素を流路系に組み込んで 用いることを考兵たとき好ましい結果である。また，過去の報告 では雨酵素を含むキット（Determiner TC-555）を POD，TOOS 怙よび 4-AA などの発色剂とともに水溶液として用いるが，この 埸合，調製した液は一週間以内に使用しなければならず，固定化 酵案を用いる方法がより優れた結果を示した。固定化酵案を水中 に分散させたステンレススチール製充埧用リザバーにとり，これ に接続したステンレススチール製カラムに充嫔したところ，得ら れた固定化酵案カラムは活性を示さなかった。さらに充填した固 定化酵素をカラム外に取りだし，これに血清ならびに発色剂を加 えて温䀧しても活性は得られなかった。すなわち，本研究で用いた 固定化酵案はステンレススチール部分との接触によって容易に失 活することがわかったので，ガラス製リザバーを用いてガラス彆 耐压カラム（内径 $2 \mathrm{~mm}$, 艮さ $5 \mathrm{~cm}$ ) に充埙して用いた。このガ ラス佂カラムを図 1 に示したシステムに組み込み、ヒト血清を注 入したところ，このときもピークの発現はなかった。しかしなが ら，このシステムからステンレススチール製分離用カラムを除去 し，ガラス製固定化酵慗カラムのみを具借した系にヒト血清を注 入したところ，1本の鋭いピークを椧出した。よってシステム中 のステンレススチール表面の存在が固定化酵慗の活性発現に対す る阻富を行ならと解釈し，ステンレススチール製カラムから耐压 ガラス製 G $5000 \mathrm{PW}$ カラム（内径 $8 \mathrm{~mm}$ ，長さ $30 \mathrm{~cm}$ )を用いた ところ，図３に示すよらなピークの発現をみた。な蚁四中には， $280 \mathrm{~nm}$ で検出した血中タンパクの分離パターンも示した。これ はリポタンパクの分雁バターン認識は行なわないが，今回使用し た 2 栕類の分離用カラム系でカラム少化のモニターとして有効で あった。しかしながら四中で示されたよらに，得られた $550 \mathrm{~nm}$ で検出したクロマトグラム中にはヒト血清の粘性によると考えら れる鋭いディップが現われ，ピークの位看および定置性に問題を 残した。このディップ発現は, 種々の市肘の简易型 HPLC 用ポ ンプ（たとえばミルトンロイ社製 5 SK 25 GK-A 型）を用いても 


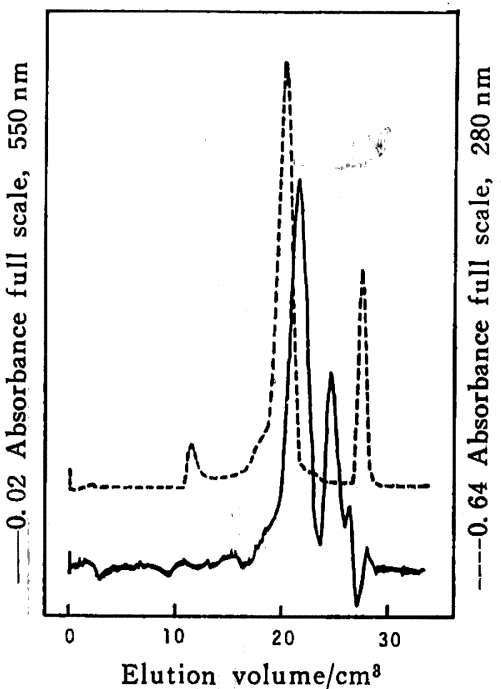

Fig. 3 Elution profile of normal human serum obtained by the immobilized enzyme method with a poorly controlled pump

The solid and dot lines were obtained by monitoring at $550 \mathrm{~nm}$ and $280 \mathrm{~nm}$, respectively

Conditions ; Pump ; 5 SK 25 GK-A, Column ; G 5000 PW, Sample; Human serum (cholesterol content being $2.32 \mathrm{~g} / \mathrm{dm}^{3}$ ), Sample volume ; $2 \times 10^{-2} \mathrm{~cm}^{8}$, Main path eluent; $150 \mathrm{mmol} \cdot \mathrm{dm}^{-8}$ phosphate buffer ( $\mathrm{pH} 7.0)$ containing $2 \mathrm{mmol} \cdot \mathrm{dm}^{-3}$ EDTA, Flow rate of main path; $0.5 \mathrm{~cm}^{3} \cdot \mathrm{min}^{-1}$, Staining eluent; 150 $\mathrm{mmol} \cdot \mathrm{dm}^{-8}$ phosphate buffer ( $\left.\mathrm{pH} 7.0\right)$ containing 0.5 $\mathrm{mmol} \cdot \mathrm{dm}^{-8} 4-\mathrm{A} \mathrm{A}, 0.3 \mathrm{mmol} \cdot \mathrm{dm}^{-3}$ TOOS, 6.7 unit $\mathrm{cm}^{-8}$ POD, $1 \%$ Triton $\mathrm{X}-100$ and $2 \mathrm{mmol} \cdot \mathrm{dm}^{-\mathrm{g}}$ EDTA, Flow rate of staining path; $0.25 \mathrm{~cm}^{8} \cdot \mathrm{min}^{-1}$, Temperature ; $40^{\circ} \mathrm{C}$

除去することができなかったが，コンピューターにより微小の流 速 $\left(1 \times 10^{-6} \mathrm{~cm}^{8} / \mathrm{min}\right)$ を制御できるポンブ（CCPM，東洋曹達工

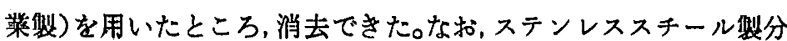
離用カラムをもったシステムでピーク発現がなかったのは，酸絭

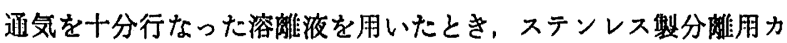
ラムを用いたときでもガラス製カラムを用いたときとまったく等 強度のピークの発現をみたことから，ステンレススチール表面で

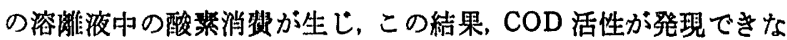
かったのであろらと考えられる。さらに，ガラス製分雁用カラム を装着した系で，水流アスピレーターを用いて十分脱気を行なっ た溶離液を用いてヒト血清を测定したところ，この場合む上とま ったく同棣のピーク発現をみた。すなわち、ステンレススチール 表面をもたないシステムを用いた場合には，通常の水流アスピレ ーターによる溶離液脱気では除去されずに溶存している酸萦腈で COD は十分に活性を発現できると考える。またこのよらな脱気 した溶離液を用いることが可能であることは，HPLC ラインでの 気泡発生を防ぐことができるという意味でも有利である。

以上の結果をふまえ，以下の実験には，ポリマーをコートした CCPM ポンプおよびインジェクター，耐圧ガラス製分晟用 (G $5000 \mathrm{PW}+\mathrm{G} 3000 \mathrm{SW}$ ，ともに内径 $8 \mathrm{~mm}$ ，辰さ $30 \mathrm{~cm}$ ) 扰よび固 定化酳要カラム (内径 $8 \mathrm{~mm}$, 長さ $10 \mathrm{~cm}$ ), テフロン製チューブ,
ポリプロピレン製ジィントを用いた。なお，固定化醭客カラム と众出器の間に位譬する反応コイルは背圧および反応時間を考虑 して，内径 $0.4 \mathrm{~mm}$ ，長さ $10 \mathrm{~m}$ のものを用いた。なお，この场 合，第一ポンブおよび第二ポンブからの送液量が $1 \mathrm{~cm}^{\mathbf{2}} / \mathrm{min}$ の場 合，通過時間は約 1.2 分であった。

つぎに溶離液および発色剂の選択を行なった。溶離液は以下の 理由を考虑に入れ，pH 7 のリン酸塩綏衙液を用いた。1） SW カ ラムはシリカを基材としており，このため使用できる溶崔夜の $\mathrm{pH}$ は 7.5 以下に制限される。2) $\mathrm{CEH}$ おび COD の至道 $\mathrm{pH}$ は7〜8であるが, POD のそれは 6 であり，3 種類の醭莱の活性 を有効に発現させるためには $\mathrm{pH} 7$ 付近の溶崔液が好ましい。3） 日本人の血液の平均的 $\mathrm{pH}$ は 7.35 7.45 であり, $\mathrm{pH} 7$ 付近の $\mathrm{pH}$ ではりポタンパク形状の变化が起こりにくいと考えられる。 また，同緩衙液の淟度は，300 $\mathrm{mmol} \cdot \mathrm{dm}^{-8}$ では試料の吸着による ピーク広がりが钼察されたため、ピーク広がりの生じない150

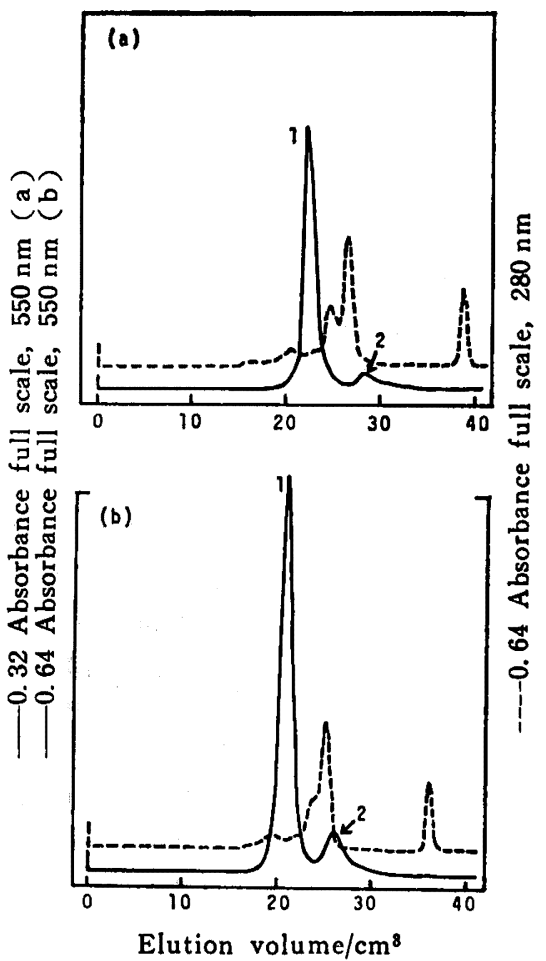

Fig. 4 Elution profile of normal human serum obtained by the method using $\mathrm{CEH}$ and COD immobilized (a) and in solution (b)

The solid and dot lines were obtained by monitoring at $550 \mathrm{~nm}$ and $280 \mathrm{~nm}$, respectively

Conditions : Pump ; CCPM, Column ; G 5000 PW + G 3000 $\mathrm{SW}$, Sample; 10 times diluted human serum (cholesterol content being $2.32 \mathrm{~g} / \mathrm{dm}^{8}$ ), Sample volume; 0.1 $\mathrm{cm}^{8}$, Main path eluent; (a) Same as in Fig. 3 and (b) $150 \mathrm{mmol} \cdot \mathrm{dm}^{-8}$ Tris buffer $(\mathrm{pH} 7.0)$, Flow rate of main path, $0.2 \mathrm{~cm}^{3} \cdot \mathrm{min}^{-1}$, Staining eluent ; (a) Same as in Fig. 3 and (b) Determiner TC-555, Flow rate of staining path $; 0.08 \mathrm{~cm}^{8} \cdot \mathrm{min}^{-1}$

Other conditions same as in Fig. 3 


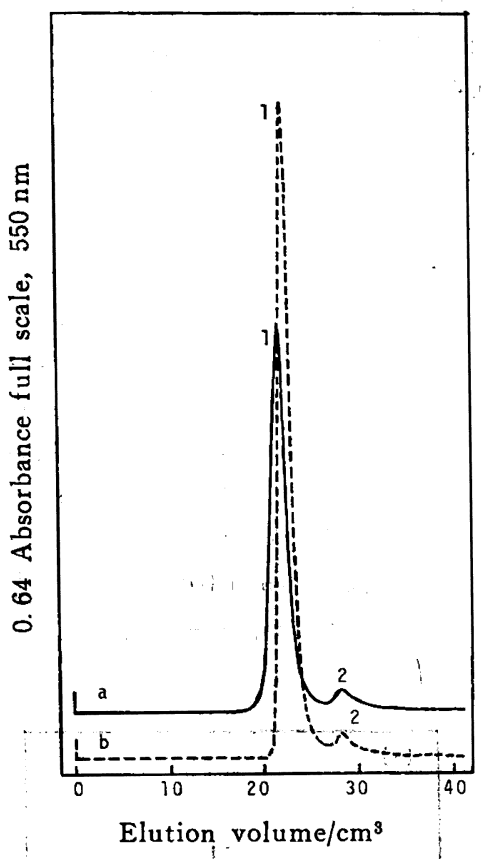

Fig. 5 Elution prifile of sera of hyperlipidemia patients obtained by the immobilized $\mathrm{CEH}$ and COD method The difference in the line shows the difference in the source

Sample; 10 times diluted serum of hyperlipidemia patient

Other conditions same as in Fig. 4 (a)

$\mathrm{mmol} \cdot \mathrm{dm}^{-8}$ を選択した。また第二ポンプで关液される発色液は， $0.5 \mathrm{mmol} \cdot \mathrm{dm}^{-3}$ 4-AA, $0.3 \mathrm{mmol} \cdot \mathrm{dm}^{-3}$ TOOS, $6.7 \mathrm{unit} / \mathrm{cm}^{8}$ POD および $1 \%$ Triton X-100 を含むるのを用いた。以上決定 したシステムを用い，健常人血清および高脂血症患者血清の測定 を行なった。測定は，採取した血清を 10 倍に希釈したものを 0.1 $\mathrm{cm}^{8}$ 注入して行なった。また第一ポンブおよび第二ポンプからの 送液量はそれぞれ $0.2,0.08 \mathrm{~cm}^{3} / \mathrm{min}$ であり，このとき反応コイ ル内の溶離液通過時間は約 4 分であった。また測定温度は室温で あり，固定化酵素カラム温度は $40^{\circ} \mathrm{C}$ であった。ここで高脂血症 は先天性と後天性のるのがあるか，Frederickson の分類によれ ば，先天性のるのは六つのタイプに分かれる25)。この中で動脈硬 化一心筋梗塞と関係の深いのは家族性高脂血症（II a 型など）お よび血型で，II a 型では血中の LDL 濃度が増加し，而型はで VLDL 濃度が增加する。健常人および 2 人の高脂血症患者血清 から得られた測定結果（クロマトグラム）をそれぞれ図 4-a およ び因 5-a および bに示した。また比較のため，前に報告された酵

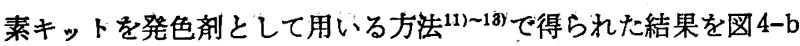
ならびに図6-a および $\mathrm{b} に$ 示した。図中，ピーク1は主として LDL K，ピーク 2 は HDL に由来することを，超遠心法で分離 して得た LDL および HDLを用いて確認した。ここで，図 4 に示した健常人および図 5 および因 6 に示した高脂血症患者から 得られたクロマトグラムのピーク部分を切り抜き総重量を測定 し，二つの方法で得られた值をプロットしたところ，両者にはよ

25) D.S. Frederickson, R. I. Levy, R. S. Lees, New. Engl. J. Med., 276, 34, 94, 148, 215, 273(1967).

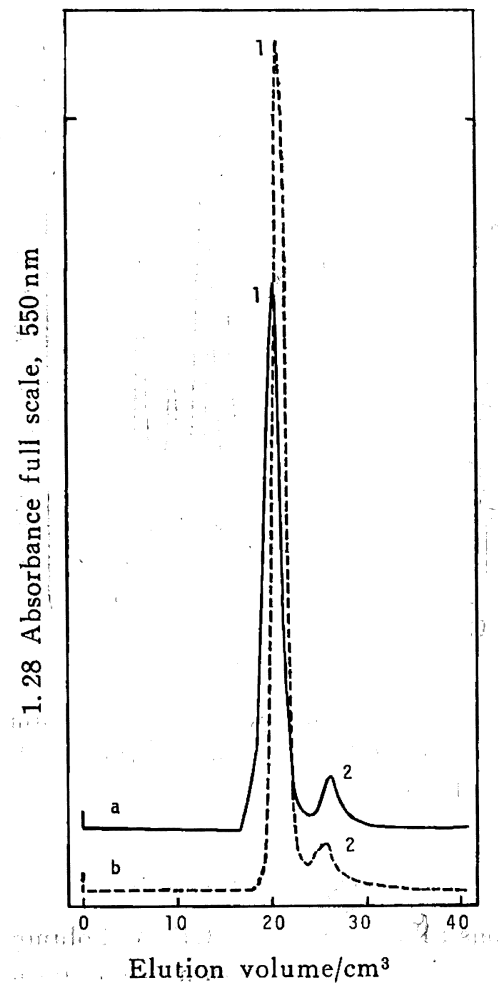

Fig. 6 Elution profile of sera of hyperlipidemia patients obtained by the method using $\mathrm{CEH}$ and $\mathrm{COD}$ in solution

The difference in the line shows the difference in the source

The line same as that in Fig. 5 shows the sample obtained from the same source

Sample; 10 times diluted serum of hyperlipidemia patient

Other conditions same as in Fig. 4 (b)

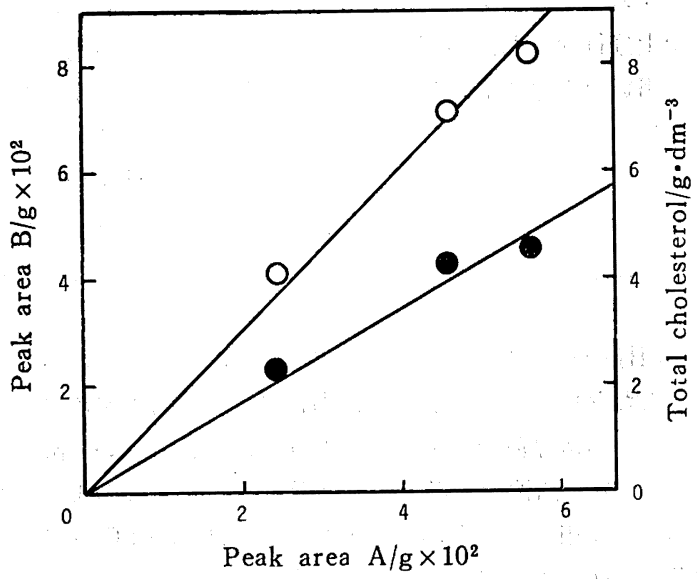

Fig. 7 Plots of the peak area (A) obtained by the immobilized $\mathrm{CEH}$ and $\mathrm{COD}$ method, against that (B) by the method using the enzymes in solution (O), and against the total cholesterol of the samples 
Table 1 Chromatographic parameters for the peaks obtained by the immobilized CEH and COD method

\begin{tabular}{|c|c|c|c|c|c|}
\hline \multirow[t]{2}{*}{ Sample serum } & \multicolumn{2}{|c|}{ Elution volume $\left(\mathrm{cm}^{3}\right)$} & \multicolumn{2}{|c|}{$\begin{array}{l}\text { Theoretical plate } \\
\text { number }(\text { per } 60 \mathrm{~cm})\end{array}$} & \multirow{2}{*}{$\begin{array}{l}\text { Peak height of } \\
\text { LDL (peak 1) } \\
\text { (Relative value) }\end{array}$} \\
\hline & Peak 1 & Peak 2 & Peak 1 & Peak 2 & \\
\hline Normal & 22.2 & 28. 3 & 1530 & - & 1 \\
\hline Hyperlipidemia 1 & 21.6 & 28. 3 & 706 & - & 1.48 \\
\hline Hyperlipidemia 2 & 22.2 & 28. 3 & 1510 & - & 2.49 \\
\hline
\end{tabular}

い相関がみられた（四 7)。また酵素キットを用いて三つの血清 から求めた総コレステロール值を本研究の方法で求めた総ピーク 重量とプロットしたところ,これも良好な関係が得られた（四 7 )。すなわち, 本研究で用いたバイオリアクター型検出器を具 備した臨床分析システムを用いた場合, 得られる結果は酵素キッ トを発色剂とする高コストのシステムで得られる結果と一致し, さらには得られるピーク面積の测定により血清中の総コレステロ ールも求めることができる。またクロマトグラム上のピーク形状 に着目し，図5-a 拈よび b のそれを図 4-a の健常人に対するピー ク形状と比較した。表 1 に, 各ピークの溶出容量, 理論段数, ピ ーク高相対値（健常人を 1 として）をまとめたが，患者 1 の血清 ではほかの二つにくらべてピーク 1 の溶出容量が小さく, またピ ーク幅が広く，これは本研究のカラム系では分離して観察するこ とはできなかったが, VLDL の LDL ピークへの重なりによるる のと考えられ， III型高脂血症の可能性が高い。一方， 2 の試料で
はピーク1の溶出容量およびピーク幅は健常人のそれと同等であ るが LDL のピーク高がきわめて高く得られた。すなわち患者 2 は LDL 量の多いII a 型高脂血症であると考えられる。

以上示したように，本研究に扣いて開発された固定化酵素を充 填したバイオリアクターを険出部にもつシステムを用いた場合， 高脂血症患者の血清を健常人のそれと識別することが可能であっ た。さらに得られたクロマトグラムのパターン分析により，表現 型で表した高脂血症の分類型も認識できることがわかった。ま たこれらの結果は前に報告された酵素キット溶液を分離後のラ インに添加する方法で得られた結果とよい相関を示した。健常人 血清を用いた測定は，同一システムで，30 回くり返し行なわれた がピークパターン拉よ゙各ピーク高は，その間不変であった。

この研究は, 文部省科学研究費補助金（特定研究「高性能化学 センサ(堣題番号, 61127003)」) の援助を受けたものである。

\title{
Special Articles on Molecular Recognition and Its Application
}

\section{A Bioreactor System for the Determination of Cholesterol Distribution in Separated Human Serum Lipoprotein Classes}

\author{
Keisuke Makino*, Ichiro Sasaki, Tohru Uenishi, Tamio TAKeuchi, \\ Ichiro $\mathrm{HARA}_{\mathrm{AR}}{ }^{*}$ and Masuo UMINO** \\ Department of Polymer Science and Engineering, Faculty of Textile Science, Kyoto \\ Institute of Technology; Matsugasaki, Sakyo-ku, Kyoto-shi 606 Japan \\ ** Scientific Instrument Division, Toyo Soda Manufacturing Co. Ltd.; Hayakawa, \\ Ayase-shi 252 Japan
}

In order to determine cholesterol distribution in human serum lipoprotein classes, which has been known to be directly related to heart-attack deseases, a bioreactor-type detection system consisting of cholesterol ester hydrorase (CEH) and cholesterol oxidase (COD) immobilized on size-exclusion chromatographic gel (TSKgel G6000 PW) was combined with size-exclusion chromatographic separation of the lipoproteins. Glass separation columns packed with G5000 PW and G $3000 \mathrm{SW}$ were found to be suitable for the separation. CEH and COD were coimmobilized on the gel activated with glutaraldehyde and packed into a glass column, which was connected to the exit of the separation column array. To the inlet of the enzyme column, introduced was staining fluid composed of peroxidase, 4aminoantipyrine, $N$-ethyl- $N$-(2-hydroxy-3-sulfopropyl)- $m$-toluidine, and Triton X-100. In this system, cholesterol ester in the lipoproteins could be converted into cholestenone and subsequently thus released $\mathrm{H}_{2} \mathrm{O}_{2}$ could be stained in a Teflon reaction coil attached to the exit of the column. Upon using a polymer-coated pump, precisely controlled by the computer, and polymer parts to avoid stainless steel surface in the system, the peaks due to low density and high-density lipoproteins appeared in the chromatogram. The elution 
profile of the peaks was in good agreement with that obtained by the method reported previously in which a large amount of $\mathrm{CEH}$ and COD were consumed as staining reagents. From the elution volumes, the height equivalent to a theoretical plate number, and the peak area of the peaks obtained, types of hyperlipidemia could be recognized. 